\title{
GEOPHYSICS AND BUILDING DIAGNOSTICS, THEIR POSSIBILITIES AND LIMITS
}

\author{
J. Bárta ${ }^{1}$, J. Jirků ${ }^{1}$, T. Belov ${ }^{1}$ \\ ${ }^{1}$ G IMPULS Praha spol. s r.o., Czech Republic - (barta, jirku, belov)@ gimpuls.cz,
}

\author{
Commission V, WG V/7
}

KEY WORDS: Geophysics, Diagnostic, Geoelectrical methods, Seismics, Gravimetry, Magnetometry, Thermometry, Radiometry

\begin{abstract}
:
Geophysical methods and building diagnostics are non-destructive measurements which can inform about quality of rocks, hydrology conditions or artificial objects (tunnels, foundation of buildings, constructions etc.). Such methods are in the principle non - destructive without impact on environment or population. Hence these methods are mostly cheaper and more acceptable than drilling, travelling with heavy machines etc. Geophysical methods study physical fields and are divided as follows: Geoelectrical methods,Seismics,Gravimetry,Magnetometry,Thermometry,Radiometry. The geophysical measurements can be carried out on a surface of terrain, in boreholes (well logging) or in the air (airborne geophysics). The non-destructive building diagnostics use mostly measurements relating to the seismic, acoustic or nuclear properties. The time-lapse monitoring of administered objects by nondestructive methods can bring beneficial and fundamental source of information about actual conditions of managed objects. Presented non-destructive measurements use sophisticated technologies and respected geophysical companies follow international and domestic standards and legislation. Geophysicists are organized mainly in international associations such as EAGE (European Association of Geoscientists and Engineers) or SEG (Society of Exploration Geophysics). This paper presents typical examples of application of non-destructive methods to our practice.
\end{abstract}

\section{INTRODUCTION}

Non-destructive diagnostics methods are useful for management and monitoring of immovable property which was committed some administration to care. The non-destructive methods are environmental - friendly and enable activities without encroachment to legal systems, civil rights or injury to tangible properties. For that reason are these methods also exploitable for building information modelling (BIM). The typical nondestructive methods are geophysical methods, physical methods for civil engineering, defectoscopy, non-destructive testing (NDT) and some forensics methods. The non-destructive methods can be for example integrate on the start of developer activities when an enterpriser has not all information about plots or has not all rights to a building site. The non-destructive methods are mostly cheaper that boreholes, penetration or hydrogeology tests, earth works etc. The non-destructive monitoring works can also continue for arbitrary time without disturbing impact to surroundings.

The geophysical methods and most of further diagnostic measurements have sophisticated methodology and were verified by long time practice. The professional geophysical community in Czech Republic is united in Czech Geophysical Association (CAAG) and Europe communities are joined in European Association of Geoscientists and Engineers (EAGE). The geophysical methods are studied on universities and research institutes on the all world. For example in Czech Republic on Faculty of Science Charles University in Prague. The non-destructive measurement must executed a qualified experts and licenced company or institute. In Czech Republic the proving committee for geophysical concession is set up on Ministry of the Environment. The most of diagnostic measurement is controlled by EU standards. It must be said that non-destructive measurement and their evaluation is professional activity for trained teams not for dilatants without special knowledge.
We can short summarize that BIM is a process supported by various tools and advanced technologies involving the generation and management of digital representations of objects or localities. We can also say that BIM can be used by subjects which plan, design, or operate buildings and physical infrastructures, such as water, waste repository, electricity, gas, roads, railways, bridges, ports and tunnels. The non-destructive methods are ready to impartial supplement or specify absent characteristics of constructions, geology, hydrology or environment. These informations can form step by step sophisticate data bases which are usable for decision- making processes in BIM system

\section{GEOPHYSICAL METHODS}

Geophysical methods study physical fields and are divided as follows:

Gravimetry,

Magnetometry,

Geoelectrical methods,

Seismic methods,

Thermometry,

Radiometric and nuclear geophysics methods

First modern geophysical measurements for apply geological research were executed by Loránd Eötvös (Hungary) on the start of twenty century. Professor Eötvös designed Torsion Balance Apparatus which can be used also as field equipment. The gravity measurements were mainly associated with petroleum localities (Rumania, later Texas, Luisiana). Very quickly followed seismic and magnetic applications for geological objectives (oil, ore deposits, structural geology). Geophysical investigations were target mostly on classical geological tasks; the other uses (for archaeology, hydrogeology, criminology, civil engineering) follow more lately with progress 
in technologies (computers, miniaturization) and applied research. The significant role has also new economic situation (phase-out mining activities in Europe, accent on environmental questions).

\subsection{Gravimetry}

Apply gravimetry is the measurement of the strength of a gravity field on the surface or close to the surface (mining, boreholes) of the Earth. Gravimetric measurement can be applied to the solution of problems of structural and regional, economic and engineering geology.

Gravity is measured in units of acceleration, that mean in the SI system of units as $\mathrm{m} / \mathrm{s}^{2}$. Conversion unit is gal with symbol Gal, which equal to $9.80665 \mathrm{~m} / \mathrm{s}^{2}$. For practical measurement is valid formula $1 \mathrm{mgl}=10 \mu \mathrm{m} \mathrm{s}^{-2}$. A contemporary instrument used to measure gravity is known as a gravimeter. The current repeatability of measurements with a top-class apparatus on the one point is better than $5 \mu \mathrm{Gal}$. The field measurement with the gravimeter, see Figure 1.

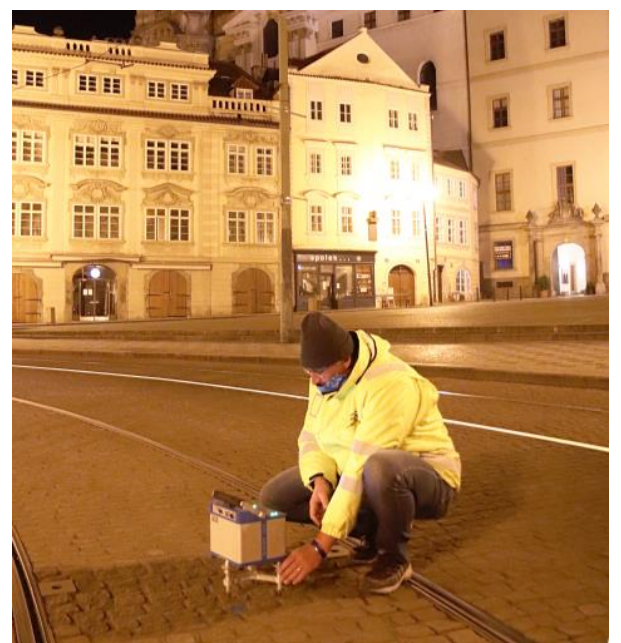

Figure 1. The gravity measurement in the centre of Prague

On the Figure 2 is presented an example of the result of gravity measurement. The negative gravity anomaly detected old dry well which was covered by roadway.

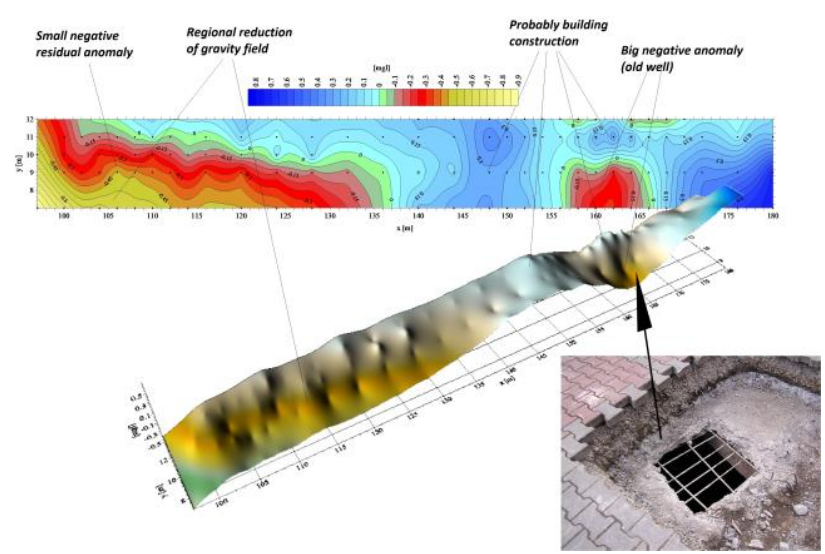

Figure 2. The $2 \mathrm{D}$ and $3 \mathrm{D}$ image of the gravity field with the finding a covered old dry well.

\subsection{Magnetometry}

The magnetic fields of geological structures are manifested as disturbances in the normal geomagnetic potential because the geological bodies contain various amounts of ferromagnetic minerals. Geomagnetic anomalies are affected by the shape, dimensions, position, depth and petrographic composition. The anomalies can be determined from field measurement and then can be quantitative or qualitative interpreted. The geomagnetic anomalies are determined as regional or local (residual) irregularities. The magnetic field is observed in units nT (magnetic induction). The conversion unit is $\gamma .1 \gamma=\mathrm{nT}$. The field measurement with the magnetometer is showed on Figure 2 and 3.

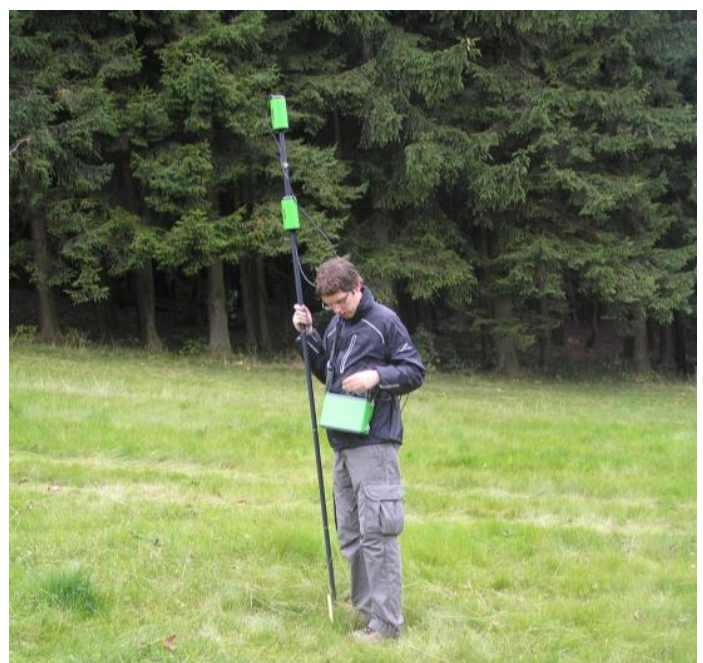

Figure 3. The gradient magnetometer in the field.

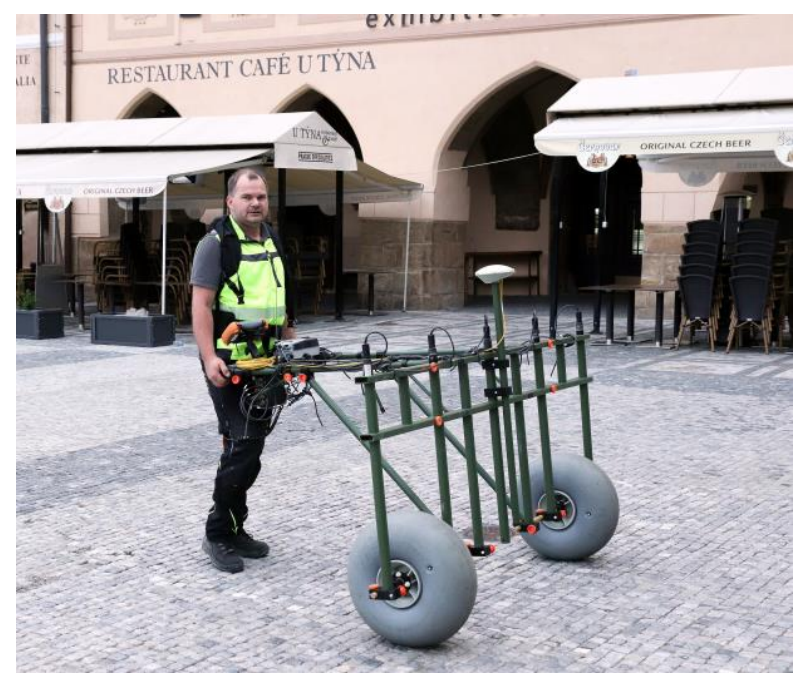

Figure 4. The multichannel magnetometer for archaeological or pyrotechnical prospection

On the Figure 5 is showed an example of quantitative and qualitative evaluation of magnetometer measurement. On the top part of the picture is map of izolines of a vertical component magnetic field. The centrum of geophysical anomaly is labelled by the cross. The ferromagnetic object is located in the depth approx. $1,5 \mathrm{~m}$. The earthworks demonstrated that ferromagnetic object is formed by ammunition material (smoke mines). 

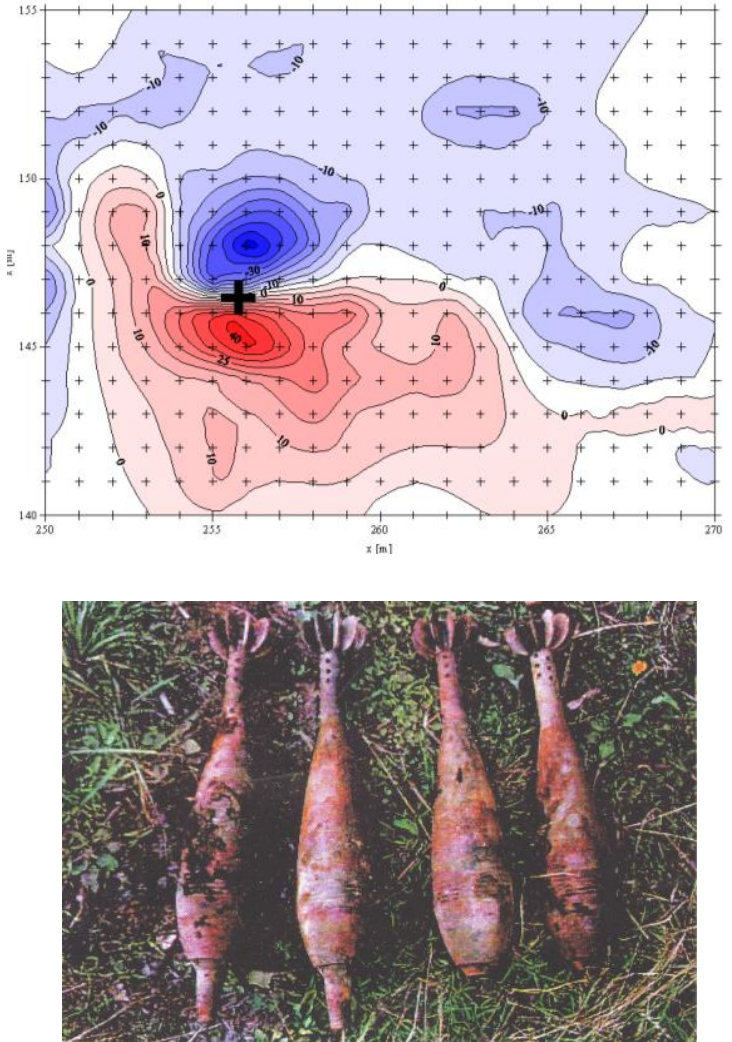

Figure 5. The example of manometry anomaly which was generated by ferromagnetic material

On the Figure 6 is presented airborne magnetic measurement. The measurement was executed on the terms of the preparation of the project of deep nuclear waste repository in Czech Republic.

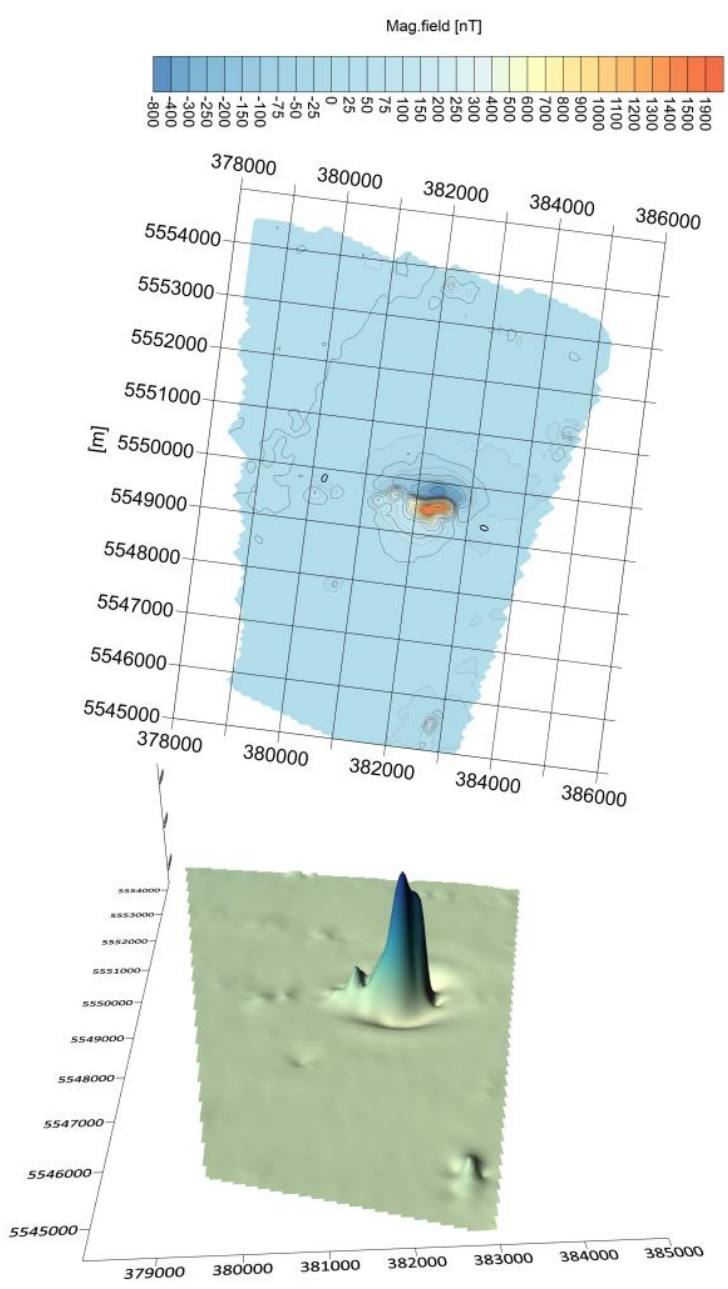

Figure 6. The example 3D and 2D presentation magnetic anomaly. The airborne measurement on the effusion of basalt (locality Blatno, Czechia)

\subsection{Geoelectrical methods}

Geoelectrical methods are frequently used set of geophysical measurements which we can divided to groups according to a type of current field which is applied:

- Natural (spontaneous) electrical field

- $\quad$ DC field

- $\quad$ EM field

\subsubsection{Natural electrical field}

Natural electrical fields are permanent phenomena in the Earth. We can used the Spontaneous Potential method (SP). In contrast to other prospective methods, this one does not require any emission circuit. This geophysical technique is based on the occurrence of certain heterogeneities conductive subsoil, which are polarized. The spontaneous polarization producing bodies are good conductors, generally with electrical continuity inside them. Anomalies of spontaneous polarization are almost always negative in the vicinity of the upper extremity of the monitored body (for example ore body). The value of the total potential difference observed varies between first hundreds of $\mathrm{mV}$ to $0.5 \mathrm{~V}$. The detected body must lie, at least in part in the active 
oxidation zone. The spontaneous potential is relatively stable over time.

On the Figure 7 is presented an ore body which is situated between oxidation medium $(\mathrm{OM})$ and reduction medium $(\mathrm{RM})$. Oxidation medium is laid above the level of the ground water $(\mathrm{H})$. The negative anomaly $(\mathrm{V})$ which we can detected on the surface is draw on the top of the picture.

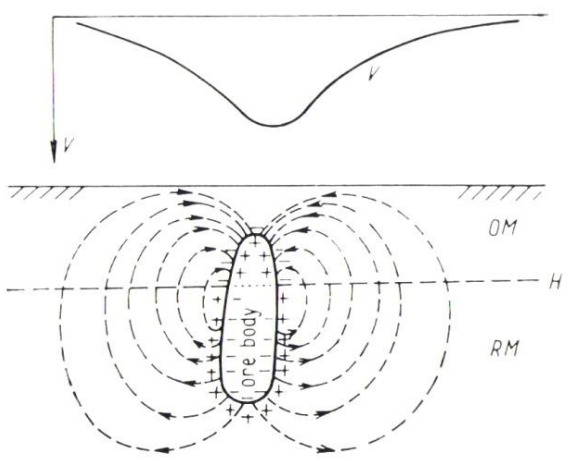

Figure 7. The generation of natural electrochemical fields in the neighbourhood of an ore body (by Mareš 1984)

In addition to classical SP method we can measure also Filtration Electrical Potentials. These potentials are generated in capillary systems (for example rock massive with water in the pores). The difference of electrical potentials is manifestation of filtration of mineralised water in the pores or rifts. On the Figure 8 is presented the typical electrical filtration anomaly of the watered tectonic zone with filtration in direction uphill or down.

\subsubsection{DC field}

The typical measurement system uses two current electrodes $(\mathrm{A}, \mathrm{B})$ and two potential electrodes $(\mathrm{M}, \mathrm{N})$. The measured reading on an apparatus is the value of potential $[\mathrm{mV}]$ and the value of current $[\mathrm{mA}]$. The final value is apparent resistivity $[\Omega \mathrm{m}]$. Please see Figure 9. The array of electrodes is known as Wenner system. The distance between A-M, N-M and M-B is the same. The Schlumberger system has the distance M-N smaller than $\mathrm{A}-\mathrm{N}$ and $\mathrm{M}-\mathrm{B}$.

In contemporary is mostly used the system Electrical Resistivity tomography (ERT). The principle of measurement is the same as in Figure 9, but we use the multichannel system of electrodes. The software integrate step by step electrodes as currents elements or potential elements. We get information from measured area (tomography data) which we can transform for example as resistivity maps.

The most of equipment for multichannel measurements can measurement not only resistivity but also induced polarization (chargeability) of rocks which are object of our interest. On the Figure 10 is showed an equipment for ERT and IP research. On the Figure 11 is presented ERT and IP cross section. The measurement found the out waste dump (see resistivity cross section) and oil leavings (see IP cross section).
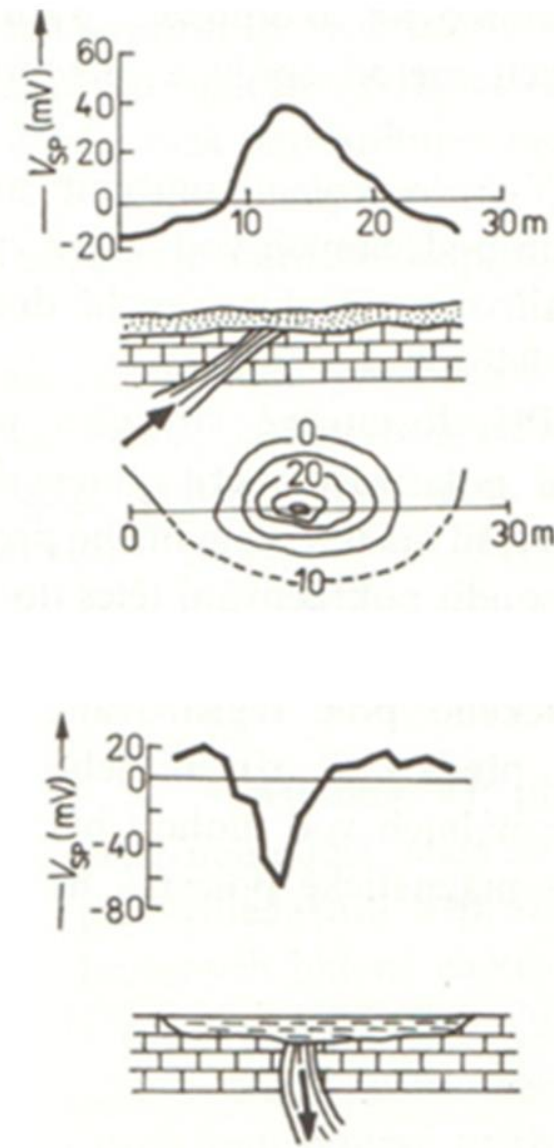

Figure 8. The generation of filtration potentials in the crack (by Karous 1989)

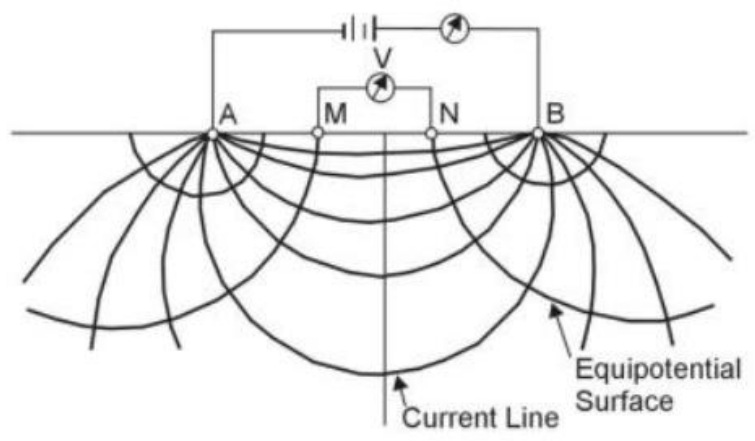

Figure 9. The disposition of electrodes A, M, N, B, current and equipotential lines (draw by U.S. Environmental Protection Agency). 


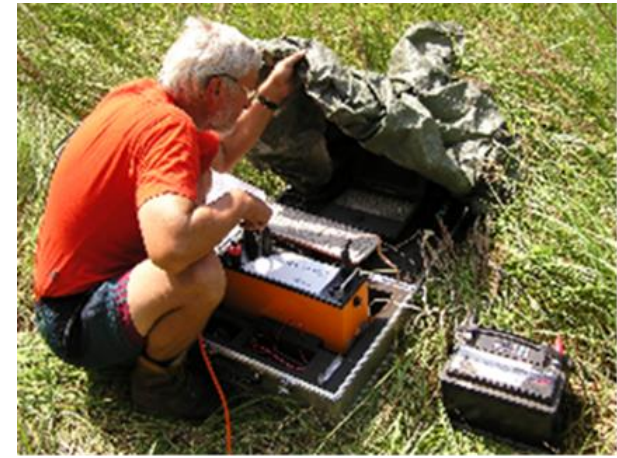

a)

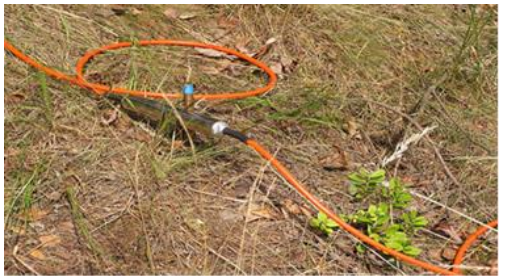

b)

Figure 10.

a) The multichannel geoelectrical apparatus ARES 2.

b) The detail with one from the set of grounded electrodes

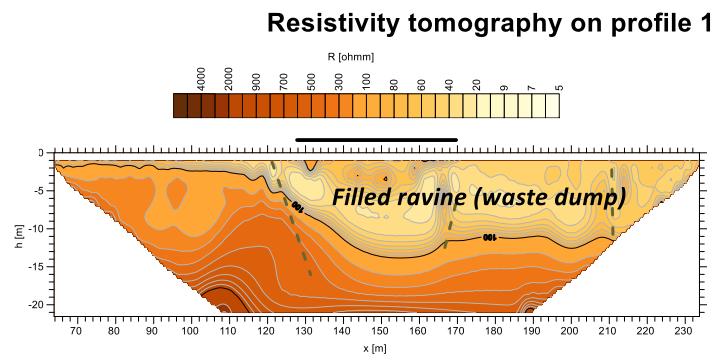

IP tomography on profile 1

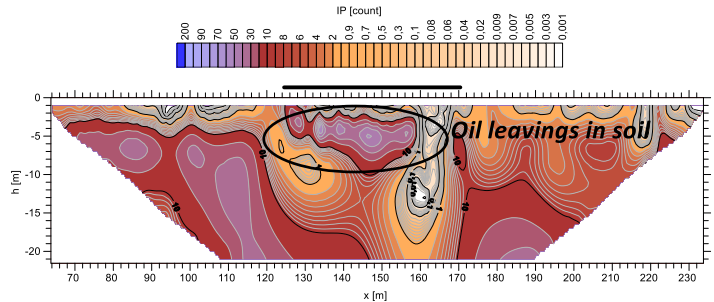

Figure 11. The resistivity cross section and IP tomography on the waste dump with oil leavings.

\subsubsection{EM field}

The electromagnetic methods of geoelectric surveying are contemporary very intensive used, but their simpler alternatives are known since the nineteen - twenties. The theoretical basis of electromagnetic methods is the theory of the electromagnetic field, the foundation of which were laid by Maxwell fundamental equations. The electromagnetic methods are very sensitive to permittivity and resistivity of the rock. Thin natural conductors like are tectonic zones and ore bodies, or artificial conductors like are cables, wires, armatures and rebars are very good detected by electromagnetic methods. The electromagnetic methods are distinguished by high productivity of works and therefore are mostly cheaper than DC methods. On the Figure
12 is presented electromagnetic equipment GEM-2 which work by method Dipole Electromagnetic Profiling (DEMP). The method DEMP uses a system Dipole-Dipole. The first dipole work as transmitter and the second as receiver. The primary electromagnetic field is influenced by characteristics of environments which we study and is detected by receiver coil.

On Figure 13 is an example of the Dipole Electromagnetic Profiling (DEMP measurement). We presented the detailed contour maps from Ghanjyan Blur site (Armenia). This area consists of the stone objects relics (shapes of medieval houses or prehistoric graves) covered by remarkably thick overlying sediments. The DEMP measurement was checked also magnetic measurement. On the Figure is a situation when the geophysical research discovered the two perpendicular structure (foundations of a wall).

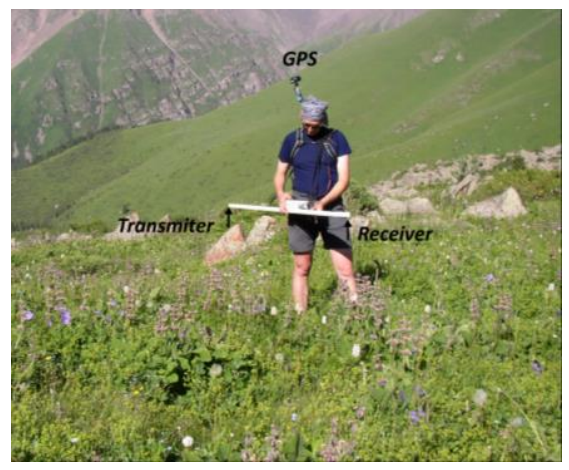

Figure 12. The electromagnetic apparatus GEM-2

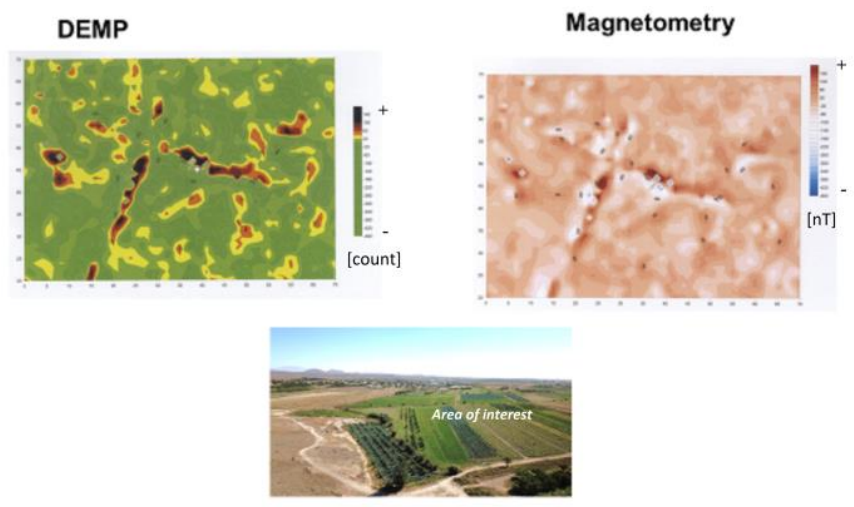

Figure 13. The locality Ghanjyan Blur site, Armenia. The DEMP and magnetic measurement discovered the two perpendicular structure.

The well-known electromagnetic methods is geological radar (GPR). The geological radar in the work is showed on the Figure 14. The radarograms with reflexes of the hidden fire reservoir from second war is presented on the Figure 15. 


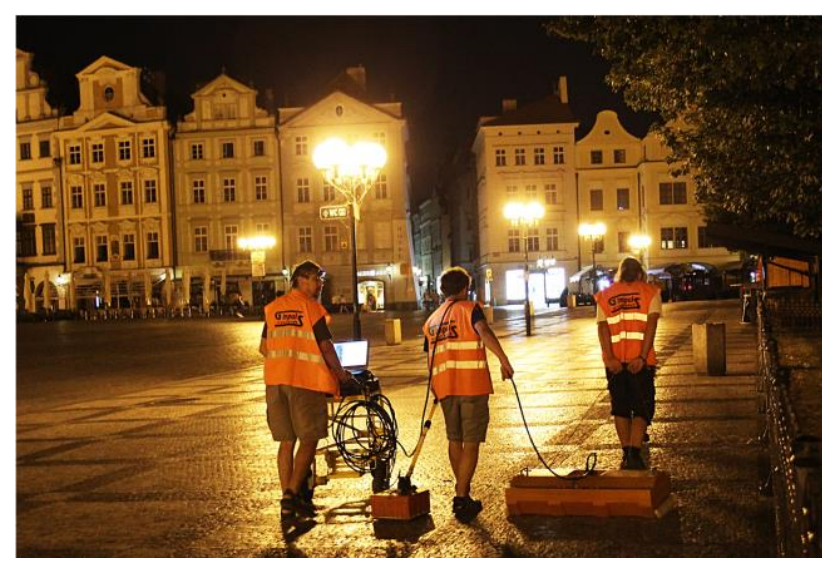

Figure 14. The GPR equipment with two antennas (see boxes on the pavement) in the work.
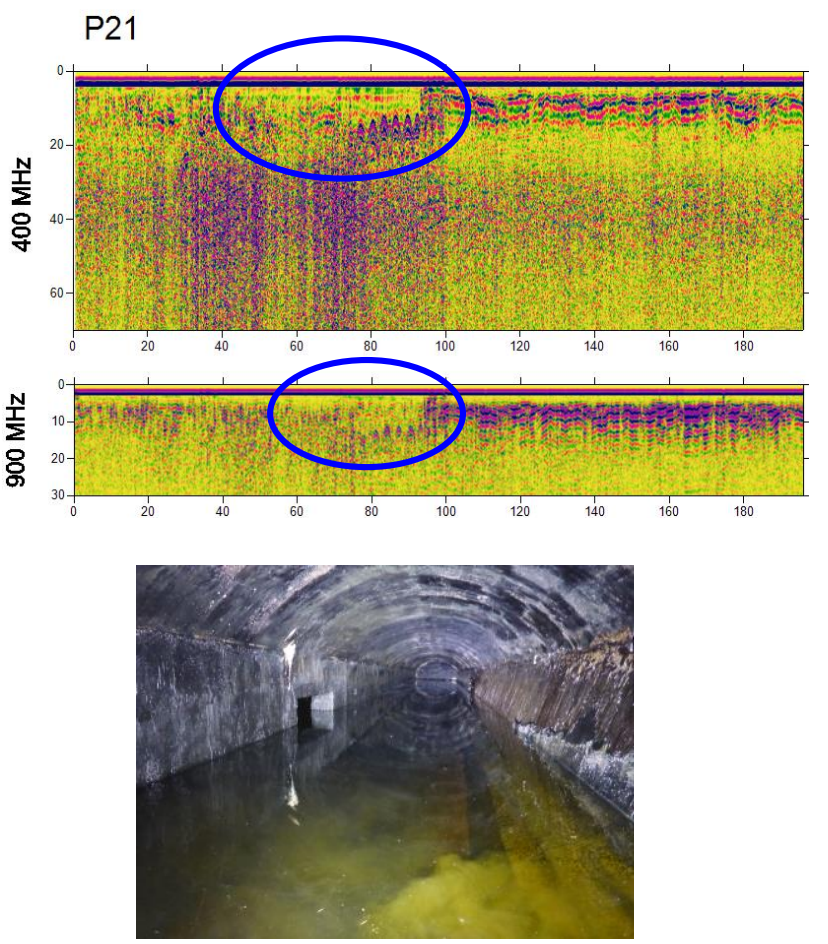

Figure 15. The GPR measurement detected hidden water reservoir.

\subsection{Seismic methods}

Seismic prospecting is a set of methods for investigating the geological (or other) structures. The seismics can study artificially exited elastic waves, but also can passive study natural exited waves (earthquakes) or seismic noise. The seismic prospecting method is divided to two principal group:

\section{- Refraction seismics}

\section{- Reflexion seismics}

In seismic reflection method the waves travel downward initially and are reflected at some point back to the surface, the overall path being essentially vertical. In seismic refraction method, principal portion of the wave-path is along the interface between the two layers (with different velocities or density) and hence approximately horizontal.

For praxis of civil engineering is important the special seismic waves which is called surface waves. The surface waves are object of observation by method Multichannel analysis surface waves (MASW). The interpretation by MASV inform about principal geotechnical parameters as module elasticity, Poisson number, velocity of longitudinal or transversal waves or differences of density of geological layers.

The seismic waves and their physical nature have directly relation to geotechnical properties and that's way the seismic methods have irreplaceable position in complex of civil engineering and geotechnical prospection.

For first orientation we can say that with accretion of seismic velocity comes about accretion of modulus elasticity and reduction of Poisson number. The longitudinal waves have higher velocity than transversal velocity or surface waves.

The seismic velocity is in seismic prospection reed mostly in $\mathrm{m} / \mathrm{s}$. The perfect crystalline rock is characterised seismic velocity of longitudinal wave round $5000 \mathrm{~m} / \mathrm{s}$. The intensively weathered crystalline rock has seismic velocity lower than $2000 \mathrm{~m} / \mathrm{s}$. Loams have velocity round hundreds of $\mathrm{m} / \mathrm{s}$.

In the Figure 16 is illustrative picture with seismic waves which we can detected of passive or active sources.

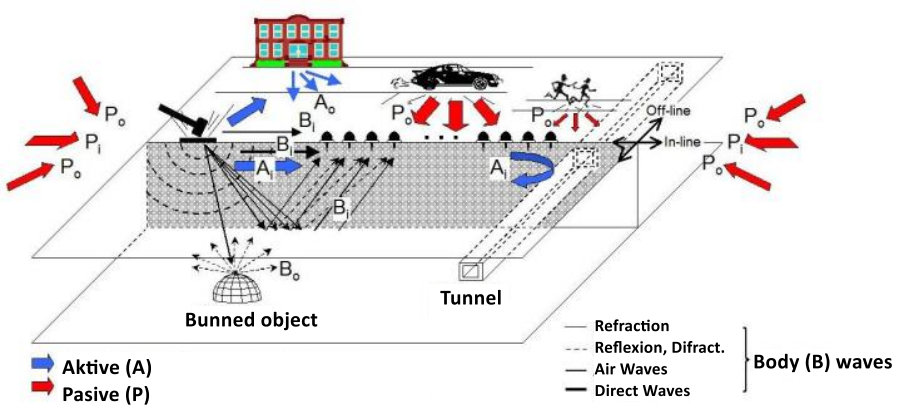

Figure 16. The illustrative picture explaining the origin of complex seismic images created as the sum of active and passive seismic sources. Taken from open webs.

In the Figure 17 is showed an example seismic cross section with interpretation. The seismic profile was situated on the top of small dam site. The seismic measurement was arranged like combination of a refraction seismics and a reflection seismics. The principal information from the prospection is knowledge of the shape of the bedrock which is formed by sandstones. The sandstones are on the surface intensive weathered.

In the Figure 18 is presented seismic field work with 48 channel seismic equipment Terraloc Mk6. The seismic waves is created by the special impact mechanism. 

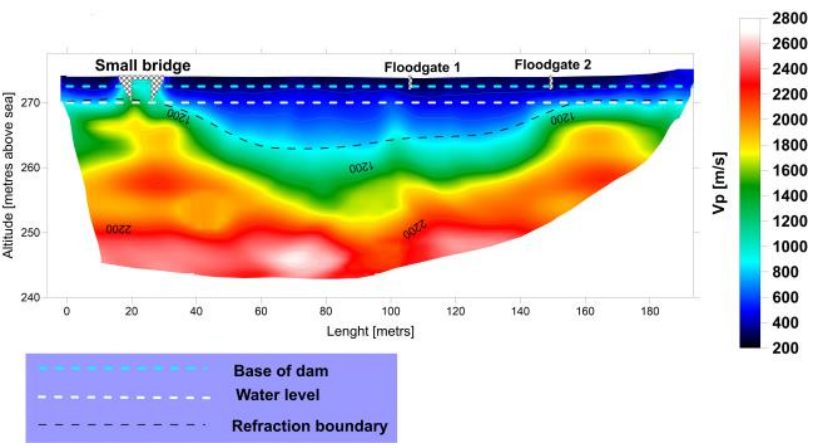

Figure 17. The seismic cross section from a small dam (central territory of the Czechia).

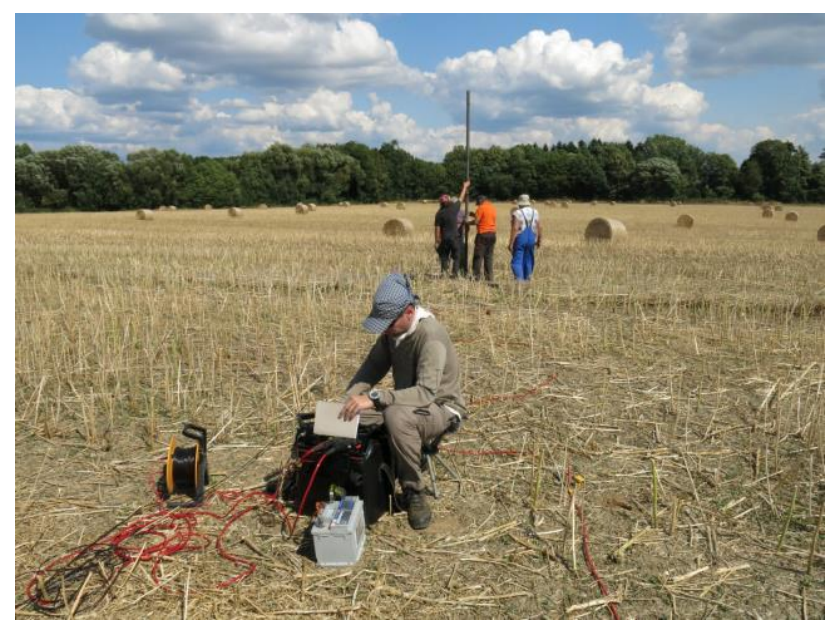

Figure 18. The seismic measurement in a field. In the front is seismic equipment, in background is seismic resource (impact mechanism).

\subsection{Thermometry}

The thermometry is not ordinary part of classical geophysical complex. The first practical explorations for geothermal studies is documented approximately in the half of twenty century. These studies solved a basic research in regional scale or practical tasks witch were relate to thermal bath. The principal problems for this research was low technology level of thermometers. Contemporary situation is very different. For example popular thermal imaging cameras are accessible, reliable and with resolution round $0.1^{\circ} \mathrm{C}$. These technology progress brings about extensive application of thermometry and this method is widely used as typical method for building diagnostic. For illustration, see Figure 19, a thermo monitoring of a distribution net by thermocamera.

\subsection{Radiometric and nuclear geophysics methods}

The radiometric methods and methods of nuclear geophysics were joined with intensive exploration of uranium deposits after Second World War. In this time the radiometric methods are used mainly for basic geological research, environmental studies and geophysical well logging. Frequently the nuclear geophysics is used for determination of density of rocks, density of porosity or thickness of the soil layers.

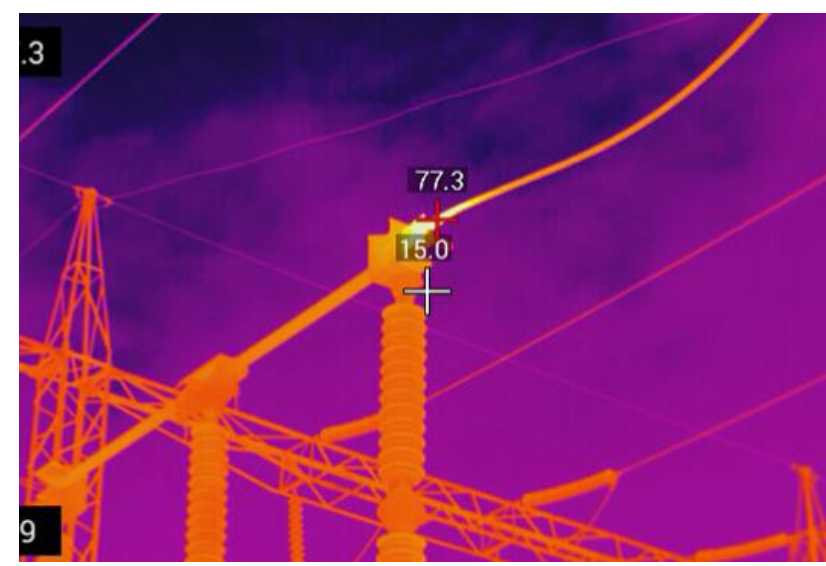

Figure 19. The snap of distribution net by thermo camera. The temperature 77.3 and 15 is reading in $\mathrm{C}^{\circ}$.

The frequently radiometry method is Gamma Spectrometry in variant air borne measurements, land measurements or well logging. The output from measurement are as follows

- Amount of total gamma [cps]

- Amount of U [cps]

- Amount of Th [cps]

- Amount of K [cps].

On the Figure 20 is showed the map of total gamma activity which was measured by the air borne gamma spectrometry on a promising area for deep underground repository in Czechia. The area is formed by granite. The maximal anomalies of cps indicate that area is formed by two generation of granite.
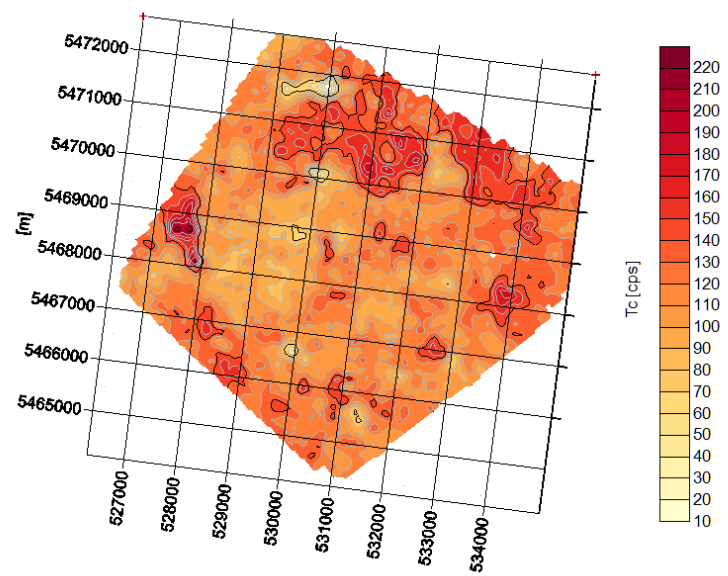

Figure 20. The map of total gamma activity. The air borne gamma spectrometry on a promising area for deep underground repository in Czechia.

On the Figure 21 is presented the radon anomaly which is interpreted like a tectonic zone (crack zone). Radon is a chemical element with the symbol $\mathrm{Rn}$ and atomic number 86 . It is a radioactive, colorless, odorless, tasteless noble gas. This gas is to be frequently found in disrupted rock massive. 

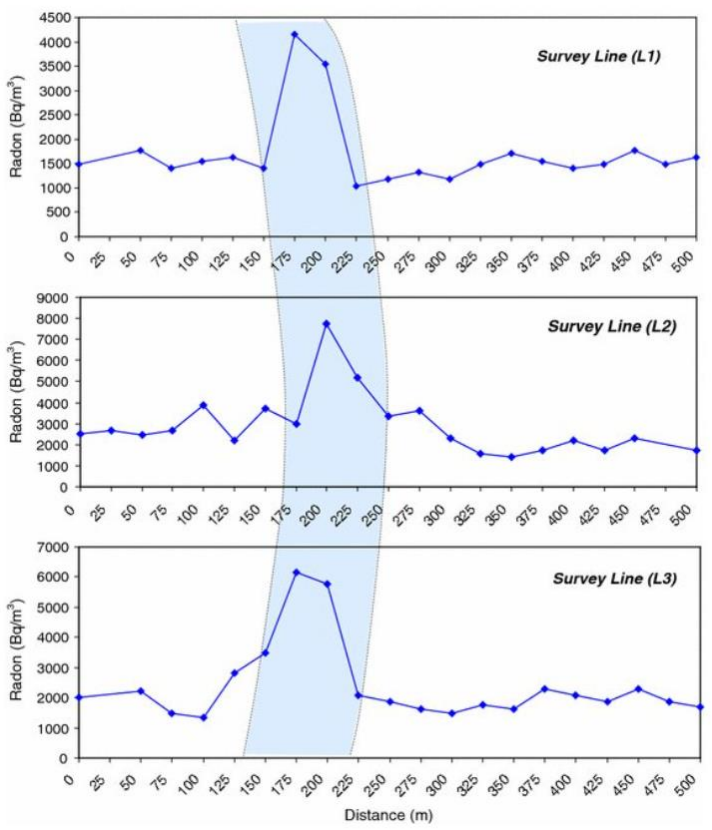

Figure 21. The tectonic zone (crack zone) detected by emanometry. The zone is manifested like radon anomaly. By Mohamed Al-Hilal, Syria.

\section{BUILDING DIAGNOSTIC METHODS}

The building diagnostics method use practically the same physical principles like geophysical methods, but buildings methods are more minds on civil engineering. These one is executed not only by geophysical experts but also frequently by civil engineers, electric engineers or other. Is clear, that fields of activity sometimes overlap. Is reality, that geophysical experience are used also in other profession like archaeology, criminology or agricultural.

For first concept we can enumerate:

- Geoelectrical measurement for an assessment of hazard of corrosion

- Technical seismicity

- Pile integration test (PIT)

- Seismic testing of quality (solidity) of concrete construction

- Dynamic impact test

- Radon gas testing (hygiene)

- Testing (density, porosity and dimension of building elements) by nuclear methods

- Geophysics for archaeology

- Geophysics for criminology

- Determination of a thickness of a mud on the bottom of a pond.

The hazard of corrosion of building constructions is in principle problem with the vagabond (parasitic) currents which are originated from bad isolated electricity systems like electric railroads, above - ground or ground electric cables and electric generators. The vagabond currents get into metal elements of a building structures (reinforcement, armature, fittings etc.) and are the cause of corrosion of construction. In Czech Republic for assessment of vagabond currents is principal technical standard ČSN 038372 (see literature). The Tab. 1 from ČSN 038372 sumarizes of the mainly principles for interpretation measured data.

\begin{tabular}{|c|c|c|c|}
\hline $\begin{array}{c}\text { Resistivity } \boldsymbol{\rho} \\
{[\mathbf{\Omega} \mathbf{m}]}\end{array}$ & $\begin{array}{c}\text { Current density } \\
\mathbf{J}_{\mathbf{p}}\left[\mathrm{mA} / \mathbf{m}^{\mathbf{2}}\right]\end{array}$ & $\begin{array}{c}\text { Characterization } \\
\text { of corrosion }\end{array}$ & Level \\
\hline more how 100 & less how 0.0001 & low & I \\
\hline $50-100$ & $0.0001-0.003$ & medium & II \\
\hline $23-50$ & $0.003-0.1$ & raised & III \\
\hline less how 23 & more how 0.1 & top-level & IV \\
\hline
\end{tabular}

Table 1. The review according to ČSN 038372

The basic information about protection against corrosion by stray current from direct current systems is presented in European standard EN 50162:2004, see literature.

The geoelectrical measurement for detection of vagabond currents and determine of resistivity of the rocks (or soil) is standard task for geophysical group (measurement of electrical potentials and vertical electrical sounding or ERT).

The technical seismicity present passive seismic measurements which detect seismic vibrations which are created by movement of machines, by activities of mining, by traffic and so on. The technical seismicity in Czechia is solved in accordance ČSN 730040:1995 (see literature) and by EN 1998-1 Eurocode 8 (see literature).

The pile integration dynamic tests (PIT) are special seismic high frequency measurements. The impact of a seismic hammer on the top of a pile generates seismic wave. On a knowledge of frequency, seismic velocity and time of the travel from the point of impact to point of geophone, we can describe quality (integrity) of a pile. The standard for PIT is published in ASTM D5882-16 (see literature). On the Figure 22 is shoved the principle of the method, possibilities and limits for this seismic measurement.

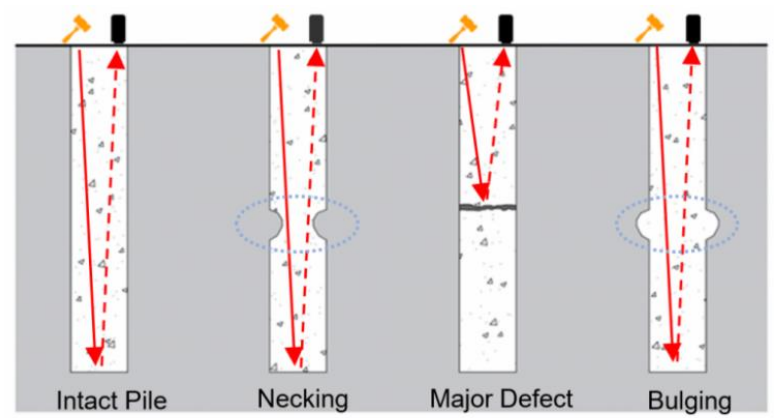

Figure 22. The principle of the PIT, possibilities and limits. By Geotech.

The dynamic impact test is a broad term for different equipment which observe impact of small desk or sphere on a surface of testing mater (soil, rock, concrete). The well-known is for example the Schmidt hammer. The Schmidt hammer, or a rebound hammer or concrete hammer test, is a small device to measure the elastic properties or strength of concrete or rock, mainly surface hardness and penetration resistance.

The impact load test with a light dynamic plate, which is presented on Figure 23, is used especially in quality control of earthworks on line constructions, embankments, backfills and backfills of sewers, improved soils, etc. Thanks to its low weight and easy handling, it is suitable for places where it is not 
possible to perform a static load test (e.g. bridge transition areas, backfills around pillars etc.).

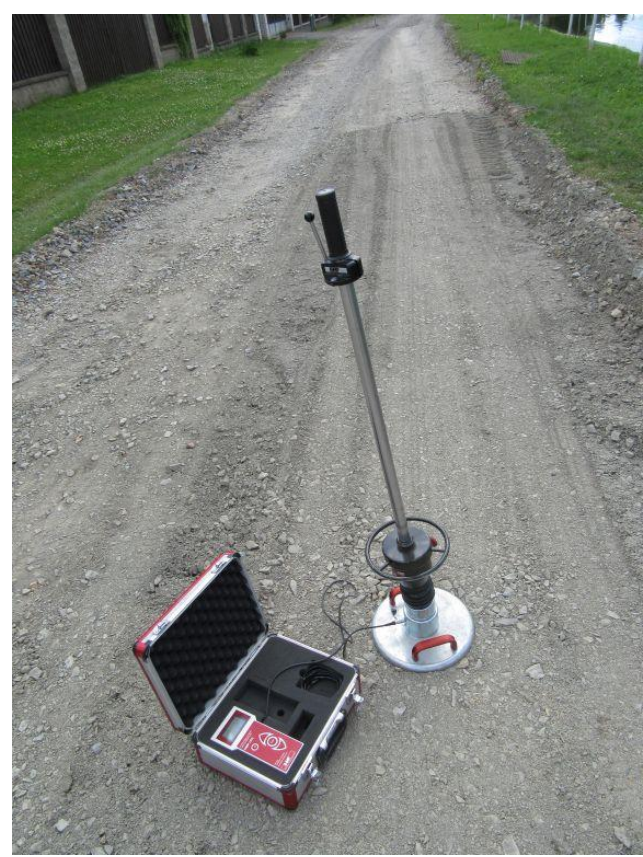

Figure 23. The equipment for the impact load test with a light dynamic plate. By ArtepGeo.

The determination of a thickness of a mud on the bottom of a pond is solved mostly by G.P.R. geophysical method, sometimes with combination with a sonar or E.R.T. The knowledge of the thickness of the mud is required for projecting of remediation of the water reservoirs.

\section{CONCLUSIONS AND NEW POSSIBILITIES}

The geophysical methods and diagnostic methods is extensively branched out profession. The presented article is only short guide which were tasked with point out potential of this methods for preparation building projects and for administration of realities. The geophysical methods and diagnostic measurement are non-destructive, that's means these activities are more easily workable than activities which can endanger environment (work with heavy machines, drilling etc.). The implementing ascent of these methods is in the first place hard data, graphs or physical maps which can be easily and objective interconnected with other project information. For deeper insight to geophysical knowledge is possible recommend for example books (see literature) Bárta 2018, Baker 1999, Barton 2006, Bensson 1982, Butler 2005, Everett 2014, Griffin 1995, Grinbaum 1965, Mareš 1984 and Semjenov 1980.

The detailed information about geophysical works for archaeology is discussed by Frolík (see article in actual the BIM Conference). The Technical seismicity is discussed by Kaláb (see article in actual BIM Conference).

The current trend in diagnostic (or geophysical) measurement is application 4D observation, that mean track changes of physical conditions in the time (4D, fourth dimension is time). This idea can be used also for monitoring different objects (geological object, foundations, and constructions) of realities which is trusted to maintenance. The optimal monitoring system must be robust, measurement must be managed by automatic system and informations are send to centrum by internet. In Underground
Research Workplace Bukov (PVP Bukov, the laboratory for preparation of Underground Repository for Radioactive Waste in Czech Republic) works such a system. The system is named SGI 1 (seismics, geoelectrics, and internet 1). The system tracks integrity of the rock massive; provides seismic and resistivity data, which is further interpreted. More information see literature, journal Bárta 2020 or literature, research project Bárta 2017. The snap with system SGI 1, see Figure 24. The box in the foreground is Seismic Centre. In the background is Centre for Geoelectrical Measurement. Above of equipment are line of electrodes and seismic sensors.

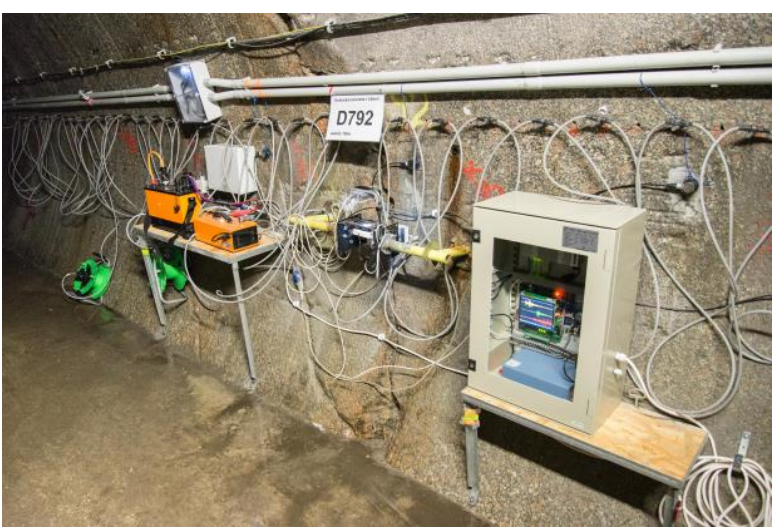

Figure 24. The system SGI 1. Locality Bedřichov, Jizerské hory. The field research for TA 03020408.

The geophysical and detection methods must execute educated (certificated) experts. In Czech Republic is responsible for a process which give licences to projection, execution and evaluation of geophysical work the Ministry of Environment of Czech Republic. The licence for special work, geophysics for terrestrial communications, confers the Ministry of traffics Czech Republic. The licence for geotechnical research confers Czech Chamber of Autorized Engineers and Technicians in Constructions.

\section{ACKNOWLEDGEMENTS}

The authors would like to thank the Radioactive Waste Repository Authority and the Technical Agency of the Czech Republic for enabling research to monitor the integrity of the rock mass.

\section{REFERENCES}

ASTM D5882-16 Standard Test Method for Low Strain Impact Integrity Testing of Deep Foundations. ASTM International.

Bárta, J., Belov, T., Jirků, J., Slavík, L., Vilhelm, J., 2020: První zkušenosti s monitorovacím geofyzikálním systémem SGI 1 na podzemním výzkumném pracovišti Bukov (First experience with monitoring geophysical system SGI 1 at Bukov underground research site). Exploration Geophysics, Remote Sensing and Environment XXVII.1 (2020)

Bárta, J., Dostál, D., Jirků, J., Slavík, L., Vilhelm J., 2017: TA 03020408, Monitoring chování puklinových systémů horninového masivu geofyzikálními metodami. (Monitoring of behaviour of fracture systems in the rock mass using geophysical methods). Technologická agentura České Republiky (Technology Agency Czech Republic) 
Bárta, J., (editor), 2018: Možnosti geofyzikálních metod při ověrování nejasných strukturně geologických, popř́padè jiných vztahů na lokalitách při průzkumu a nápravě starých ekologických zátěži. (Possibilities of geophysical methods in verifying unclear structural-geological or other relationships at sites during the exploration and correction of old ecological burdens.) Manual Ministerstva životního prostředí České republiky. (Manual of the Ministry of the Environment of the Czech Republic)

Baker, G.S., 1999: Processing near surface seismic-reflection data: A Primer. Society of Exploration Geophysicist.

Barton, N., 2006: Rock quality, seismic velocity, attenuation and anisotropy. Taylor and Francis Group, London.

Benson, R.C., Glaccum, R.A., Noel, M.R., 1982: Geophysical techniques for sensing buried wastes and waste migration. U.S. Environmental Protection Agency, Las Vegas Nevada

Butler, D.K., 2005: Near-surface geophysics. Society of Exploration

ČSN 038372: Principles for the reduction against corrosion of nonlinear installations stored in the ground water. $C Z$ standard.

ČSN 730040:1995 Zatížení stavebních objektů technickou seismicitou a jejich odezva (Loads of technical structures by technical seismicity). Český normalizační institut. Official Journal L 189, 18/07/2002 P. 0012 - 0026

Directive 2002/49/EC:2002 relating to the assessment and management of environmental noise. European Parliament and of the Council.

EN 1997-1:2004 Eurocode 7: Geotechnical design - Part 1: General rules. European Committee for Standardization.

EN 1997-1:2004 Eurocode 7: Geotechnical design - Part 2: Ground rules. European Committee for Standardization.

EN 1998-1 Eurocode 8: Design of structures for earthquake resistance - Part 1: General rules, seismic actions and rules for buildings. European Committee for Standardization.

EN 50162:2004: Protection against corrosion by stray current from direct current systems. European Committee for Electrotechnical Standardization.

EN 16907: 2018 Earthworks - Part 2: Classification of materials. European standard.

Everett, M.E., 2014: Near-surface applied geophysics. Springer Science + Business media Dordrecht

Griffin, R.H., commander, 1995: Geophysical exploration for engineering and environmental investigations. Engineer Manual, US Army Corps of Engineers

Grinbaum, I.I., 1965: Geofizičekije metody opredelenija filtracionnych svojstv gornych porod. Nedra, Moskva

Mareš, S. et al., 1984: Introduction to applied geophysics. D. Reidel Publishing Company.

Semjenov, A.S., 1980: Elektrorazvedka metodom jestestvennogo polja. Leningrad, Nedra
Zákon 44/1988 Sb., Zákon o ochraně a využití nerostného bohatství (horní zákon), ve znění účinném k 1.2.2022. (Act on the Protection and Use of Mineral Wealth (Mining Act), in the version effective as of 1.2.2022), Sbirka zákonů.

Zákon č. 62/1988 Sb. Zákon České národní rady o geologických pracích a o Českém geologickém úřadu v posledním znění. (Act of the Czech National Council on geological works and on the Czech Geological Office in the last version). Sbirka zákonů. 